\title{
Apresentação do número temático Quadrinhos em Tradução
}

\section{Rodrigo Faveri e Dennys Silva-Reis (Orgs.)*}

O estudo de interesse acadêmico sobre os quadrinhos na universidade se origina juntamente com a atenção dedicada a outras formas de mídia narrativa popular de consumo de massa, em especial o cinema e outras mídias visuais. Este já não é mais um fenômeno acadêmico exatamente recente, há já certa tradição no estudo dos quadrinhos que perdura, no Brasil, por aproximadamente 40 anos. A primeira obra que temos sobre o assunto específico da tradução de quadrinhos é de cunho prático e pedagógico, abordando apenas o campo linguístico do texto - referimo-nos a Oficina de tradução do francês: traduzindo quadrinhos de Maria Lúcia Jacob D. Barros de 2009. E, apesar desta constatação, investigar a prática da tradução de quadrinhos pode-se dizer que é novo. Isto é mais interessante naquelas culturas em que a tradição dos quadrinhos é intimamente ligada à pratica de sua tradução e inclusão no sistema de circulação local como é o caso no Brasil.

O simpósio de Quadrinhos em Tradução realizado no XI Congresso Internacional da ABRAPT 2013/setembro, na Universidade Federal de Santa Catarina, foi o primeiro evento que se sabe até então dedicado somente ao assunto e que reuniu pesquisadores de diferentes áreas, regiões do país e segmentos (tradutores, professores, pesquisadores em nível de mestrado e

\footnotetext{
" Gostaríamos de agradecer ao Prof. Dr. Mauri Furlan (UFSC) pelo trabalho editorial e o apoio fornecido na primeira etapa da organização deste dossiê.
} 
FAVERI, R.; SILVA-REIS, D. - Apresentação do número temático - Quadrinhos em Tradução

doutorado) ${ }^{1}$. Com onze apresentações de seus participantes, durante todo o dia, estivemos com a audiência repleta. Outros colegas se juntaram a nós; outros, impedidos, não puderam comparecer. Mas o germe de um grupo se constituiu. E havíamos conseguido construir algo em comum, uma ideia, senão completa, ao menos parcial, com alguns dos elementos que caracterizam os quadrinhos de comum acordo. Uma definição tentativa e parcial do objeto de interesse do tradutor e do leitor de quadrinhos no que tange aos Estudos de Tradução.

O que são quadrinhos? Há muitas definições e também uma forte insistência na ideia de que não é possível defini-los. Entre as definições possíveis, no entanto, pode-se dizer que os quadrinhos são um tipo de texto multimodal no qual a propriedade narrativa é atribuída pela sequencialidade que se pode inferir a partir da justaposição de recursos multimodais (de natureza imagética e de natureza linguística), os quais produzem efeitos narrativos essenciais como temporalidade e espacialidade.

Os quadrinhos não são uma forma menor de literatura. Mesmo que os quadrinhos sejam compreendidos como um produto cultural híbrido pertencente a um determinado estágio de desenvolvimento da cultura, eles representam uma forma autônoma da necessidade de expressão narrativa que caracteriza as culturas e os grupos sociais como o caso dos mangás e os fanzines.

Ao final do evento em 2013, comentávamos entre os presentes a respeito deste sentimento, algo como uma exclusividade, advinda de uma combinação inusitada entre sistemas de significação imagéticos, linguísticos e outros recursos gráficos específicos dos quadrinhos. Estes se caracterizam por um tipo de texto narrativo que compartilha elementos com outros tipos narrativos como o cinema, histórias ilustradas, animações, entre outros.Também se pode mencionar a fotonovela, fenômeno ideológico e

\footnotetext{
${ }^{1}$ O simpósio foi originalmente proposto e coordenado por Rodrigo Faveri com a colaboração e participação do Prof. Dr. Paulo Ramos (Unifesp).
}

TradTerm, São Paulo, v. 27, Setembro/2016, pp. 7-10 www.usp.br/tradterm http://www.revistas.usp.br/tradterm/index 
FAVERI, R.; SILVA-REIS, D. - Apresentação do número temático - Quadrinhos em Tradução

midiático que perdurou no Brasil por muito tempo, uma espécie de quadrinhos para adultos que segue os mesmos padrões das HQs.

$\mathrm{Na}$ ocasião da realização do simpósio, afirmávamos a necessidade de explorar a variedade de fenômenos associados à prática e à teoria da tradução de quadrinhos. Evento cultural de inegável impacto no mercado editorial e nas práticas de letramento contemporâneas, as HQs ocupam lugar peculiar na investigação dos fenômenos envolvidos e nas práticas de tradução (ZANETTIN 2008). Isto se deve à característica multimodal do texto que compõe os quadrinhos, ao combinar recursos gráficos e recursos linguísticos na sua construção narrativa. Dada esta sua natureza e por se constituir como um gênero reconhecidamente pervasivo culturalmente, os quadrinhos propõem problemas únicos à teoria e à prática da tradução pelo fato de conjugarem dois registros semióticos em sua constituição. Um dos exemplos dessa problemática é a questão da adaptação que pode ser vista como prática de tradução intersemiótica (adaptação de literatura), processo de tradução editorial (HQ estrangeira traduzida), ou tradução visual - processo de tradução de um tradutor/desenhista (grosso modo: apagar um desenho e pôr outro).

Após o simpósio, alguns dos participantes explicitaram suas percepções a respeito do fato de que estávamos diante de um tipo de tradução reconhecível, porém sobre a qual não dispúnhamos ainda, pelo menos no Brasil, de um corpo teórico e/ou de pesquisas que nos ajudassem e indicassem soluções para os problemas que os trabalhos individuais apresentavam. Mas a criatividade tem a liberdade de agir nestes casos e foi o que os participantes fizeram, foram criativos, e isto é possível perceber nos textos que se seguem.

A partir da iniciativa da realização do simpósio, começa a se constituir um pequeno conjunto de propostas a respeito da tradução de quadrinhos. Somado a isso, pode-se perceber que se multiplicam teses, dissertações e artigos sobre o assunto, mas que se encontram dispersos entre as revistas acadêmicas e os bancos de dados das bibliotecas brasileiras, o que nos impulsionou ainda mais para a confecção do presente dossiê. 
FAVERI, R.; SILVA-REIS, D. - Apresentação do número temático - Quadrinhos em Tradução

A chamada linguagem dos quadrinhos não é a mesma da narrativa em prosa, e possivelmente esteja mais perto da narrativa poética e da propaganda. A reflexão sobre sua tradução não pode depender exclusivamente da tradição, ou tradições, de tradução. Ao mesmo tempo, sua prática é bastante difundida e o público dos quadrinhos no Brasil consome e depende proporcionalmente em um percentual muito maior da tradução do que de obras produzidas originalmente no país.

O presente dossiê apresenta uma série de artigos submetidos pelos participantes do simpósio e outros participantes interessados em problemas relacionados à prática e à reflexão da tradução de quadrinhos. Apesar de haver muitas outras possiblidades de abordagens, pensamos que os artigos que aqui se encontram são apenas uma ponta do iceberg deste campo dos Estudos de Tradução que começa a se firmar no Brasil. Agradecemos imensamente a todos os colaboradores deste número pela paciência, criatividade e qualidade das pesquisas.

Gratidão especial a John Milton pela intermediação entre os organizadores do dossiê e a revista TradTerm e ao comitê editorial e técnico da revista em nome da professora Lineide Mosca pela paciência, presteza, colaboração e boa aceitação dos textos aqui publicados.

Por fim, desejamos a todos uma boa leitura e esperamos que os temas abordados sejam elucidativos para os problemas que a tradução de quadrinhos apresenta a tradutores e leitores hoje no Brasil.

TradTerm, São Paulo, v. 27, Setembro/2016, pp. 7-10

www.usp.br/tradterm

http://www.revistas.usp.br/tradterm/index 